\title{
Weight maintenance and protein intake of the young rat
}

\author{
By L. R. NJAA \\ Government Vitamin Laboratory, Norwegian Fisheries Research Institute, \\ Bergen, Norway
}

(Received 8 Fanuary $1965-$ Accepted I Fuly 1965$)$

Evaluation of protein quality by the criteria of net protein utilization (NPU), biological value (BV) and other similar measurements requires assumptions about the protein needs for purposes other than growth (Mitchell, 1923-4; Bender \& Doell, I957; Miller \& Payne, 196r; Njaa, I963). This portion of the total protein need is subsequently referred to as the 'maintenance requirement' of protein. The maintenance requirement is not a well-established quantity either for the rat or for other species. Barnes, Bates \& Maack (1946) reported that the maintenance protein requirements of young and adult rats were nearly the same and in terms of egg protein equal per $100 \mathrm{~cm}^{2}$ of body surface to about I I $\mathrm{mg} \mathrm{N} /$ day. This is equivalent to I $40-150 \mathrm{mg}$ $\mathrm{N} /$ day $\mathrm{kg}^{0.73}$ for rats ranging in weight from $5^{\circ}$ to $25^{\circ} \mathrm{g}$. The requirement for egg protein for maintenance of nitrogen balance found by Forbes, Vaughan \& Yohe (1958) was about $0.9 \mathrm{mg} \mathrm{N} /$ day $\mathrm{g}^{0.75}$ which is equivalent to $160-180 \mathrm{mg} \mathrm{N} / \mathrm{day}^{\mathrm{kg}}{ }^{0.73}$ for the same body-weight range. The (USA) National Research Council's (1959) Committee on Amino Acids put the basal protein requirement at $880 \mathrm{mg} / \mathrm{day}_{\mathrm{kg}}{ }^{0.734}$ (Smuts, 1935) or about $140 \mathrm{mg} \mathrm{N} /$ day $\mathrm{kg}^{0.73}$, increased by $10 \%$ to allow for metabolic faecal loss of N. Recently Miller \& Payne (1963, 1964) suggested that the maintenance requirement is much higher, namely $250 \mathrm{mg} \mathrm{N} / \mathrm{day}^{\mathrm{kg}}{ }^{\cdot 73}$. Their estimate (Miller \& Payne, I964) was based on their own results obtained with young rats and pigs (Miller \& Payne, I962), and on some results selected from the literature. Njaa (I962) pointed out that the maintenance item used by Miller \& Payne ( $196 r$ ) was higher than generally accepted values. This communication reports experiments designed to obtain estimates of the protein levels and the corresponding protein intakes required to maintain bodyweight of young rats when given eight protein sources with widely different chemical scores. By multiplying the intakes by the chemical scores estimates of the maintenance requirement of ideal protein have been obtained. The results indicate that at $22^{\circ}$ this requirement is slightly less than $200 \mathrm{mg} \mathrm{N} /$ day $\mathrm{kg}^{0.73}$ and that at $28^{\circ}$ the requirement is less than at $22^{\circ}$.

\section{EXPERIMENTAL}

\section{Animals and technique}

Young white rats from our own colony were weaned at $2 \mathrm{I} \pm \mathrm{I}$ days and were given a stock diet containing about $20 \%$ protein $(\mathrm{N} \times 6 \cdot 25)$ until they weighed between 50 and $60 \mathrm{~g}$, usually at $25^{-28}$ days. The rats were then used in the experiments. Each experiment was with four or five groups of five or six rats, the rats being divided into 
the groups according to sex and body-weight, and usually also according to litters. Only one protein source was tested in each experiment, except in Expt 9 when five protein sources were compared. The rats were kept individually in wire cages and they were usually given the experimental diets for $\mathrm{I} 2-\mathrm{I} 5$ days. This length of period was chosen because in determinations of NPU and BV each diet is usually given for periods extending from 9 to 14 days (Mitchell, r923-4; Miller \& Bender, I955; Njaa, 1959). In two experiments (Expts 8, 13 ) the experiment lasted longer $(23$ and 65 days). The food was given either $a d$ lib. or in restricted daily amounts. The food cups were changed daily and the food residues and spillings were collected. Water was added to the diets to reduce spilling, but in one experiment (Expt ro) wet and dry diets were compared. The rats were weighed daily just before the food cups were changed, except on Sundays and other holidays.

The animal rooms were kept at $22 \pm I^{\circ}$ in all experiments except in Expt II in which a comparison was made between this temperature and $28 \pm 1^{\circ}$.

The composition of the diets was as described by Njaa (1959); the protein content was varied by reciprocal variations in the contents of the protein source and partly dextrinized potato starch. In Expt to a mixture of raw potato starch and rice starch was compared with dextrinized potato starch.

Maintenance of body-weight was judged from the slopes of the curves of weight gain against time calculated for the period following the first 4 or 5 days (rate of weight change, g/day). In Expt 8 the slope for days $13^{-23}$ was calculated and in Expt 14 the slopes were calculated for the entire period. Maintenance of body-weight was judged to have been attained when the slope values were not significantly different from zero or were less than $\mathrm{O} \cdot \mathrm{I} \mathrm{g} / \mathrm{day}$. The maintenance protein levels or the corresponding intakes of ideal protein were estimated by relating the slopes so obtained to the protein levels or to the intakes of ideal protein ( $\mathrm{N}$ intake $\times$ chemical score) by fitting smooth lines to the points. In arithmetical presentation these lines were usually sigmoid. The intersections of the lines with the ordinate corresponding to zero slope were taken as estimates of the maintenance protein levels or of the maintenance requirement of ideal protein.

The criteria adopted allow only rough estimates of the maintenance protein level to be made. They do not take into consideration that the body composition of the rats may be changing during the experiment within and between groups. However, the data available in the literature indicate only small changes in the $\mathrm{N}$ content of rats given different types of diet (Bender \& Doell, 1957; Henry \& Toothill, 1962; Čabak, Dickerson \& Widdowson, 1963).

\section{Protein sources and chemical scores}

The protein sources used are listed in Table $\mathrm{I}$. The egg albumin was spray-dried hen's egg white, the herring meal was a flame-dried whole meal, the casein was a rennet casein dried in a casein dryer at $60-65^{\circ}$, the soya-bean meal was solventextracted and heat-treated, the linseed meal was solvent-extracted, the pea meal was made from dried uncooked green peas, the wheat gluten was plate dried at $35-70^{\circ}$ 
and the zein was obtained from the firm Dr Th. Schuchardt, Munich, Germany. The chemical scores of egg albumin, casein, soya-bean meal, pea meal and wheat gluten were taken from the FAO (1957) publication, those of herring meal, linseed meal, and fortified zein were calculated from the FAO (1957) provisional amino acid pattern with amino acid data taken from Boge (1960), Siemermann (1959) and Block \& Mitchell (1946-7), respectively. In herring-meal protein, methionine plus cystine was assumed to be the limiting entity ( $\mathrm{Njaa}, \mathrm{I}$ 196I). The protein contents listed were not determined in this study but represent rounded values of determinations made in connexion with other experiments.

Table I. Protein contents $(N \times 6 \cdot 25)$ and chemical scores of the protein sources used

$\begin{array}{lcc}\text { Protein source } & \begin{array}{c}\text { Protein } \\ \text { content } \\ (\%)\end{array} & \begin{array}{c}\text { Chemical } \\ \text { score } \\ (\%)\end{array} \\ \text { Egg albumin } & 80 & 100 \\ \text { Herring meal } & 70 & 90 \\ \text { Casein } & 80 & 80 \\ \text { Soya-bean meal } & 48 & 70 \\ \text { Linseed meal } & 34 & 70 \\ \text { Pea meal } & 23 & 60 \\ \text { Wheat gluten } & 83 & 40 \\ \text { Zein + 1.3\% L-lysine hydrochloride } & 92 & 30 \\ \quad+0.9 \% \text { DL-tryptophan } & & \end{array}$

\section{Design of experiments}

Expts I-8. The protein sources listed in Table I were given at four protein levels as indicated in Table 2. At least the lowest was believed to be below the maintenance level for the particular protein source. The rats given wheat gluten were continued on new diets for an additional I I-day period after the initial I2-day period; the other experiments lasted from 12 to 14 days (Table 2 ).

Expt 9. Five of the protein sources used in Expts 1-8 were retested at a protein level believed to be near to the maintenance level as judged from the previous results. Egg albumin was tested at a protein level of $\mathrm{I} \cdot 6 \%$, herring meal at $2 \cdot 0 \%$, linseed meal at $2.9 \%$, wheat gluten at $3.4 \%$ and pea meal at $4.9 \%$. The experiment lasted for I2 days (Table 2).

Expt 10. Egg albumin was given at the $2 \cdot 3 \%$ protein level in diets containing either partly dextrinized potato starch $(67.5 \%)$ or a mixture of raw potato starch $(15 \%)$ and rice starch $(52.5 \%$ of the diet). The $\mathrm{B}$ complex vitamins which usually were pipetted as solutions into the diet ( $\mathrm{Njaa}, \mathrm{I}$ 959) were in this experiment given as a dry mixture in partly dextrinized potato starch of which $1 \%$ was added to the diets. Both diets were given wet and dry. The experiment lasted for is days (Table 3 ).

Expt I I. Egg albumin was given at the $2 \cdot$ I and $4 \%$ protein levels; one group on each protein level was kept at $22 \pm \mathrm{I}^{\circ}$ and one group at $28 \pm \mathrm{I}^{\circ}$. The experiment lasted for 14 days (Table 4 ).

In Expts I-I I food was given ad lib.

Expts 12 and 13. Egg albumin was given at the 0,2,4 and 6\% protein levels (Expt 12) and at the $4 \cdot 2,6,8 \cdot 2$ and $10.4 \%$ levels (Expt I3). In both experiments 
Table 2. Mean daily intakes of food, calories, and nitrogen $\times$ chemical score, in groups of six (Expts 2-5, 7-9) or five (Expts I, 6) rats given eight protein sources at levels near to the assumed maintenance level

\begin{tabular}{|c|c|c|c|c|c|c|c|}
\hline \multirow[b]{2}{*}{ Expt no. } & \multirow[b]{2}{*}{ Protein source } & \multirow[b]{2}{*}{$\begin{array}{c}\text { Protein } \\
\text { content } \\
\text { of diet } \\
(\%)\end{array}$} & \multicolumn{3}{|c|}{ Daily intake } & \multirow[b]{2}{*}{$\begin{array}{l}\text { Mean } \\
\text { body- } \\
\text { weight } \\
(\mathrm{g})\end{array}$} & \multirow[b]{2}{*}{$\begin{array}{l}\text { Slope* } \\
\text { (g/day) }\end{array}$} \\
\hline & & & $\begin{array}{l}\text { Food } \\
(\mathrm{g})\end{array}$ & $\begin{array}{c}\text { Calories } \\
\left(\mathrm{kcal} / \mathrm{kg}^{0.73}\right)\end{array}$ & $\begin{array}{c}\text { Nitrogen } \times \\
\text { score } \\
\left(\mathrm{mg} / \mathrm{kg}^{0 \cdot 73}\right)\end{array}$ & & \\
\hline $\begin{array}{c}\text { I } \\
\text { (12 days) }\end{array}$ & Egg albumin & $\begin{array}{l}I \cdot 0 \\
2 \cdot 0 \\
2 \cdot 9 \\
3 \cdot 9\end{array}$ & $\begin{array}{l}7 \cdot 4 \\
8 \cdot 2 \\
8 \cdot 7 \\
9 \cdot 0\end{array}$ & $\begin{array}{l}236 \\
257 \\
263 \\
242\end{array}$ & $\begin{array}{l}100 \\
216 \\
320 \\
445\end{array}$ & $\begin{array}{l}53 \cdot 3 \\
55 \cdot 5 \\
58 \cdot 2 \\
68 \cdot 5\end{array}$ & $\begin{array}{l}(-0.19) \\
+0.66 \\
+\mathrm{r} \cdot 18 \\
+\mathrm{I} .59\end{array}$ \\
\hline (I4 days) & Soya-bean meal & $\begin{array}{l}2 \cdot 1 \\
3 \cdot 2 \\
4 \cdot 5 \\
5 \cdot 5\end{array}$ & $\begin{array}{l}6 \cdot 2 \\
7 \cdot 0 \\
7 \cdot 5 \\
8 \cdot 2\end{array}$ & $\begin{array}{l}204 \\
223 \\
231 \\
246\end{array}$ & $\begin{array}{l}126 \\
210 \\
307 \\
398\end{array}$ & $\begin{array}{l}51 \cdot 7 \\
54 \cdot 2 \\
56 \cdot 8 \\
59 \cdot 0\end{array}$ & $\begin{array}{l}-0.51 \\
-0.13 \\
+0.42 \\
+0.73\end{array}$ \\
\hline (1 3 days) & Linseed meal & $\begin{array}{l}2 \cdot 1 \\
3 \cdot 1 \\
4 \cdot 0 \\
5 \cdot 1\end{array}$ & $\begin{array}{l}6 \cdot 5 \\
6 \cdot 9 \\
7 \cdot 6 \\
7 \cdot 5\end{array}$ & $\begin{array}{l}208 \\
216 \\
228 \\
219\end{array}$ & $\begin{array}{l}129 \\
196 \\
269 \\
334\end{array}$ & $\begin{array}{l}53 \cdot 6 \\
55 \cdot 9 \\
58 \cdot 8 \\
59 \cdot 7\end{array}$ & $\begin{array}{c}-0.33 \\
(+0.22) \\
+0.97 \\
+I .22\end{array}$ \\
\hline $\begin{array}{c}4 \\
\text { (1 } 3 \text { days) }\end{array}$ & Herring meal & $\begin{array}{l}I \cdot 1 \\
2 \cdot 2 \\
2 \cdot 9 \\
4 \cdot 3\end{array}$ & $\begin{array}{l}6 \cdot 4 \\
7 \cdot 2 \\
7 \cdot 7 \\
8 \cdot 1\end{array}$ & $\begin{array}{l}207 \\
220 \\
232 \\
233\end{array}$ & $\begin{array}{r}86 \\
184 \\
249 \\
380\end{array}$ & $\begin{array}{l}53 \cdot 1 \\
57 \cdot 4 \\
60 \cdot 8 \\
62 \cdot 3\end{array}$ & $\begin{array}{c}-0.58 \\
(+0.28) \\
+1.09 \\
+1.43\end{array}$ \\
\hline $\begin{array}{c}5 \\
\text { (1 } 4 \text { days) }\end{array}$ & Casein & $\begin{array}{l}1 \cdot 0 \\
2 \cdot 0 \\
3 \cdot 1 \\
4 \cdot 2\end{array}$ & $\begin{array}{l}5 \cdot 4 \\
6 \cdot 2 \\
7 \cdot 3 \\
7 \cdot 2\end{array}$ & $\begin{array}{l}180 \\
203 \\
224 \\
220\end{array}$ & $\begin{array}{r}61 \\
137 \\
235 \\
312\end{array}$ & $\begin{array}{l}51 \cdot 1 \\
52 \cdot 3 \\
56 \cdot 9 \\
57 \cdot 4\end{array}$ & $\begin{array}{l}-0.55 \\
-0.36 \\
+0.30 \\
+0.33\end{array}$ \\
\hline $\begin{array}{c}6 \\
\text { (14 days) }\end{array}$ & Fortified zein & $\begin{array}{r}6 \cdot 8 \\
7 \cdot 7 \\
8 \cdot 9 \\
10 \cdot 1\end{array}$ & $\begin{array}{l}5 \cdot 4 \\
5 \cdot 2 \\
5 \cdot 5 \\
5 \cdot 5\end{array}$ & $\begin{array}{l}179 \\
173 \\
179 \\
183\end{array}$ & $\begin{array}{l}\text { I } 53 \\
\text { I } 68 \\
187 \\
232\end{array}$ & $\begin{array}{l}5 I \cdot 3 \\
5 I \cdot 0 \\
5 x \cdot 5 \\
5 I \cdot 4\end{array}$ & $\begin{array}{l}-0.45 \\
-0.45 \\
-0.40 \\
-0.44\end{array}$ \\
\hline $\begin{array}{c}7 \\
\text { (12 days) }\end{array}$ & Pea meal & $\begin{array}{l}2 \cdot 9 \\
4 \cdot 0 \\
4 \cdot 6 \\
5 \cdot 6\end{array}$ & $\begin{array}{l}7 \cdot 3 \\
7 \cdot 3 \\
7 \cdot 4 \\
7 \cdot 7\end{array}$ & $\begin{array}{l}245 \\
237 \\
243 \\
244\end{array}$ & $\begin{array}{l}180 \\
240 \\
279 \\
345\end{array}$ & $\begin{array}{l}50 \cdot 5 \\
51 \cdot 7 \\
52 \cdot 8 \\
54 \cdot 8\end{array}$ & $\begin{array}{c}-0.36 \\
-0.32 \\
(+0.1 I) \\
+0.39\end{array}$ \\
\hline $\begin{array}{c}8 \\
(\text { day } I-12)\end{array}$ & Wheat gluten & $\begin{array}{l}4 \cdot 4 \\
5 \cdot 5 \\
6 \cdot 5 \\
7 \cdot 8\end{array}$ & $\begin{array}{l}6 \cdot 7 \\
6 \cdot 6 \\
6 \cdot 7 \\
6 \cdot 7\end{array}$ & $\begin{array}{l}239 \\
212 \\
238 \\
233\end{array}$ & $\begin{array}{l}160 \\
195 \\
219 \\
274\end{array}$ & $\begin{array}{l}53 \cdot 6 \\
54 \cdot 1 \\
53.9 \\
55.8\end{array}$ & $\begin{array}{c}(+0.07) \\
+0.21 \\
+0.25 \\
+0.43\end{array}$ \\
\hline $\begin{array}{c}8 \\
\text { (day } 13-23 \text { ) }\end{array}$ & Wheat gluten & $\begin{array}{l}4 \cdot 0 \\
5 \cdot 0 \\
5 \cdot 9 \\
7 \cdot 0\end{array}$ & $\begin{array}{l}6 \cdot 8 \\
6 \cdot 4 \\
6 \cdot 5 \\
6 \cdot 4\end{array}$ & $\begin{array}{l}212 \\
198 \\
200 \\
188\end{array}$ & $\begin{array}{l}144 \\
166 \\
199 \\
222\end{array}$ & $\begin{array}{l}55 \cdot 6 \\
56 \cdot 3 \\
56 \cdot 8 \\
60 \cdot 3\end{array}$ & $\begin{array}{l}+0.24 \\
+0.27 \\
+0.31 \\
+0.36\end{array}$ \\
\hline $\begin{array}{c}9 \\
\text { (12 days) }\end{array}$ & $\begin{array}{l}\text { Egg albumin } \\
\text { Herring meal } \\
\text { Linseed meal } \\
\text { Pea meal } \\
\text { Wheat gluten }\end{array}$ & $\begin{array}{l}I \cdot 6 \\
2 \cdot 0 \\
2 \cdot 9 \\
4 \cdot 9 \\
3 \cdot 4\end{array}$ & $\begin{array}{l}6 \cdot 1 \\
6 \cdot 6 \\
6 \cdot 7 \\
6 \cdot 4 \\
6 \cdot 8\end{array}$ & $\begin{array}{l}197 \\
211 \\
211 \\
202 \\
213\end{array}$ & $\begin{array}{l}132 \\
159 \\
181 \\
251 \\
123\end{array}$ & $\begin{array}{l}53 \cdot 2 \\
54 \cdot 0 \\
54.6 \\
55 \cdot 0 \\
55 \cdot 3\end{array}$ & $\begin{array}{l}-0.45 \\
-0.19 \\
(-0.03) \\
-0.07 \\
-0.08\end{array}$ \\
\hline
\end{tabular}

* Slope of the weight gain against time curves calculated for the period following the first 4 or 5 days. The values in parentheses were not significantly different from zero. 
the daily food ration was restricted to $4.5 \mathrm{~g} /$ rat which was eaten completely by all the rats except those in the $\% \%$ group in Expt 12 . Expt 12 lasted for ${ }_{5} 5$ days and Expt 13 for 12 days (Table 5).

Expt 14. Egg albumin was given at the I, 2, 3 and $4 \%$ protein levels for 65 days, except with the I \% group for which the period was 32 days. Restricted daily amounts of food were given for the first 46 days. The food offered was eaten completely by all the rats except those in the I \% group which refused some food from day 14 on. During the first 8 days $4.5 \mathrm{~g} /$ rat were given; for the next 6 days the ration was $5.5 \mathrm{~g}$, for the next I I days $6 \mathrm{~g}$, for the next 7 days $5.5 \mathrm{~g}$, for the next 7 days $5.0 \mathrm{~g}$, and for the next 7 days $4.5 \mathrm{~g}$. For the remaining I9 days food was given ad lib. (Table 5).

Table 3. Expt 10. Mean daily intakes of food, calories and nitrogen by groups of six rats given egg albumin diets containing either partly dextrinized potato starch and sucrose $(D)$ or raw potato starch, rice starch and sucrose $(R)$ as the carbohydrate ingredients with $(+)$ or without $(-)$ addition of water for $\mathbf{2} 2$ days

\begin{tabular}{|c|c|c|c|c|c|c|}
\hline \multirow{2}{*}{$\begin{array}{c}\text { Protein } \\
\text { content } \\
\text { of diet } \\
(\%)\end{array}$} & \multirow[b]{2}{*}{$\begin{array}{c}\text { Type of } \\
\text { diet }\end{array}$} & \multicolumn{3}{|c|}{ Daily intake } & \multirow{2}{*}{$\begin{array}{c}\text { Mean } \\
\text { body- } \\
\text { weight } \\
\text { (g) }\end{array}$} & \multirow[b]{2}{*}{ Slope* } \\
\hline & & $\begin{array}{c}\text { Food } \\
(\mathrm{g})\end{array}$ & $\begin{array}{c}\text { Calories } \\
\left(\mathbf{k c a l}^{\prime} \mathbf{k g}^{\mathbf{0 - 7 3}}\right)\end{array}$ & $\begin{array}{c}\text { Nitrogen } \\
\left(\mathrm{mg} / \mathrm{kg}^{0.73}\right)\end{array}$ & & \\
\hline $2 \cdot 3$ & $\mathrm{D}-$ & $5 \cdot 9$ & 195 & I 88 & $5 x \cdot 6$ & $(-0.09)$ \\
\hline $2 \cdot 3$ & $\mathrm{D}+$ & $5 \cdot 5$ & I 85 & 179 & $50 \cdot 3$ & $(-0.16)$ \\
\hline $2 \cdot 3$ & $\mathrm{R}-$ & $5 \cdot 8$ & 195 & $\mathrm{r} 88$ & 50.3 & -0.16 \\
\hline $2 * 3$ & $\mathbf{R}+$ & $6 \cdot 1$ & 203 & 196 & $5 \mathbf{I} \cdot \mathbf{I}$ & $(+0.06)$ \\
\hline
\end{tabular}

* Slope of the weight gain against time curves for the period following the first 4 days. The values in parentheses were not significantly different from zero.

Table 4. Expt II. Mean daily intakes of food, calories and nitrogen by groups of six rats given egg albumin diets at the $2 \cdot \mathrm{I}$ and $4.0 \%$ protein levels at 22 and $28^{\circ}$ for 14 days

\begin{tabular}{|c|c|c|c|c|c|c|}
\hline \multirow{2}{*}{$\begin{array}{c}\text { Protein } \\
\text { content } \\
\text { of diet } \\
(\%)\end{array}$} & \multirow{2}{*}{$\begin{array}{c}\text { Tempera- } \\
\text { ture } \\
\left({ }^{\circ} \mathrm{C}\right)\end{array}$} & \multicolumn{3}{|c|}{ Daily intake } & \multirow{2}{*}{$\begin{array}{l}\text { Mean } \\
\text { body- } \\
\text { weight } \\
\text { (g) }\end{array}$} & \multirow[b]{2}{*}{ Slope* } \\
\hline & & $\begin{array}{l}\text { Food } \\
(\mathrm{g})\end{array}$ & $\begin{array}{c}\text { Calories } \\
\left(\mathrm{kcal} / \mathrm{kg}^{0} \cdot{ }^{0}\right)\end{array}$ & $\begin{array}{c}\text { Nitrogen } \\
\left(\mathrm{mg} / \mathrm{kg}^{0 \cdot 73}\right)\end{array}$ & & \\
\hline $2 \cdot 1$ & 22 & $6 \cdot 3$ & 207 & 183 & $5 x \cdot 8$ & $(0.00)$ \\
\hline 4.0 & 22 & $7 \cdot 8$ & 237 & 400 & $57 \cdot 9$ & +0.80 \\
\hline $2 \cdot I$ & 28 & $4 \cdot 6$ & $15^{\circ}$ & 132 & $52 \cdot 6$ & $\left(-0 . I^{\prime}\right)$ \\
\hline 4.0 & 28 & $5 \cdot 2$ & 162 & 272 & $56 \cdot 2$ & +0.39 \\
\hline
\end{tabular}

* Slope of the weight gain against time curves for the period following the first 5 days. The values in parentheses were not significantly different from zero.

\section{RESULTS}

Graphs of cumulative weight gains are given in Figs. I-6. The protein contents of the diets used, the intakes of food, calories, and $\mathrm{N} \times$ chemical score, are given in Tables 2-5. The intakes of calories and of $\mathrm{N}$ are given on the basis of daily intake per $\mathrm{kg}$ body-weight to the power 0.73 (Miller \& Payne, 1962). The slopes of the weight gain against time curves (p. 444) are also given; the values in parentheses were not significantly different from zero. 
Table 5. Mean daily intakes of food, calories and nitrogen by groups of six young rats given restricted daily amounts of egg albumin diets at different protein levels

\begin{tabular}{|c|c|c|c|c|c|c|}
\hline \multirow[b]{2}{*}{ Expt no. } & \multirow{2}{*}{$\begin{array}{c}\text { Protein } \\
\text { content } \\
\text { of diet } \\
(\%)\end{array}$} & \multicolumn{3}{|c|}{ Daily intake } & \multirow{2}{*}{$\begin{array}{c}\text { Mean } \\
\text { body- } \\
\text { weight } \\
\text { (g) }\end{array}$} & \multirow[b]{2}{*}{ Slope* } \\
\hline & & $\begin{array}{c}\text { Food } \\
(\mathrm{g})\end{array}$ & $\begin{array}{c}\text { Calories } \\
\left(\mathrm{kcal} / \mathrm{kg}^{0 \cdot 73}\right)\end{array}$ & $\begin{array}{c}\text { Nitrogen } \\
\left(\mathrm{mg} / \mathrm{kg}^{0} \cdot 73\right)\end{array}$ & & \\
\hline $\begin{array}{c}12 \\
\text { (I5 days) }\end{array}$ & $\begin{array}{l}0.1 \\
2 \cdot 0 \\
4 \cdot 0 \\
6.0\end{array}$ & $\begin{array}{l}4 \cdot I \\
4 \cdot 5 \\
4 \cdot 5 \\
4 \cdot 5\end{array}$ & $\begin{array}{l}141 \\
152 \\
148 \\
147\end{array}$ & $\begin{array}{l}- \\
129 \\
248 \\
372\end{array}$ & $\begin{array}{l}48.8 \\
50.0 \\
52.0 \\
52.3\end{array}$ & $\begin{array}{c}-0.38 \\
-0.12 \\
(-0.06) \\
(+0.08)\end{array}$ \\
\hline $\begin{array}{c}\text { I3 } \\
\text { (12 days) }\end{array}$ & $\begin{array}{r}4 \cdot 2 \\
6 \cdot 0 \\
8 \cdot 2 \\
10 \cdot 4\end{array}$ & $\begin{array}{l}4 \cdot 5 \\
4 \cdot 5 \\
4 \cdot 5 \\
4 \cdot 5\end{array}$ & $\begin{array}{l}148 \\
148 \\
147 \\
148\end{array}$ & $\begin{array}{l}261 \\
372 \\
505 \\
640\end{array}$ & $\begin{array}{l}52 \cdot 1 \\
52 \cdot 1 \\
52 \cdot 8 \\
52 \cdot 6\end{array}$ & $\begin{array}{r}-0.10 \\
(0.00) \\
(-0.03) \\
-0.12\end{array}$ \\
\hline $\begin{array}{c}\mathrm{I} 4 \\
\text { (days } I-8)\end{array}$ & $\begin{array}{l}I \cdot 0 \\
2 \cdot I \\
3 \cdot 0 \\
3 \cdot 9\end{array}$ & $\begin{array}{l}4 \cdot 5 \\
4 \cdot 5 \\
4 \cdot 5 \\
4 \cdot 5\end{array}$ & $\begin{array}{l}152 \\
151 \\
152 \\
151\end{array}$ & $\begin{array}{r}64 \\
\text { I } 28 \\
193 \\
249\end{array}$ & $\begin{array}{l}50.2 \\
50.8 \\
49.9 \\
50.7\end{array}$ & $\begin{array}{l}- \\
- \\
-\end{array}$ \\
\hline $\begin{array}{c}14 \\
\text { (days 9-14) }\end{array}$ & $\begin{array}{l}1 \cdot 0 \\
2 \cdot 1 \\
3 \cdot 0 \\
3 \cdot 9\end{array}$ & $\begin{array}{l}5 \cdot 5 \\
5 \cdot 5 \\
5 \cdot 5 \\
5 \cdot 5\end{array}$ & $\begin{array}{l}202 \\
198 \\
202 \\
198\end{array}$ & $\begin{array}{r}86 \\
167 \\
254 \\
324\end{array}$ & $\begin{array}{l}44 \cdot 7 \\
46 \cdot 0 \\
44 \cdot 8 \\
46 \cdot 0\end{array}$ & $\begin{array}{c}(-0.08) \\
(-0.01) \\
+0.10 \\
(+0.07)\end{array}$ \\
\hline $\begin{array}{c}\mathrm{I} 4 \\
\left.\text { (days } \mathrm{I}_{5-25}\right)\end{array}$ & $\begin{array}{l}1 \cdot I \\
2 \cdot 1 \\
3 \cdot 0 \\
4 \cdot 0\end{array}$ & $\begin{array}{l}5 \cdot 5 \\
6.0 \\
6 \cdot 0 \\
6.0\end{array}$ & $\begin{array}{l}202 \\
210 \\
210 \\
203\end{array}$ & $\begin{array}{r}94 \\
187 \\
257 \\
343\end{array}$ & $\begin{array}{l}44 \cdot 6 \\
47 \cdot 6 \\
47 \cdot 5 \\
49 \cdot 9\end{array}$ & $\begin{array}{c}(-0.02) \\
+0.32 \\
+0.43 \\
+0.60\end{array}$ \\
\hline $\begin{array}{c}14 \\
\text { (days } 26-32 \text { ) }\end{array}$ & $\begin{array}{l}1 \cdot 1 \\
2 \cdot I \\
3 \cdot 0 \\
4 \cdot 0\end{array}$ & $\begin{array}{l}3 \cdot 9 \\
5.5 \\
5.5 \\
5.5\end{array}$ & $\begin{array}{l}147 \\
197 \\
188 \\
178\end{array}$ & $\begin{array}{r}68 \\
167 \\
236 \\
296\end{array}$ & $\begin{array}{l}43 \cdot 3 \\
49 \cdot 3 \\
50 \cdot 1 \\
54 \cdot 0\end{array}$ & $\begin{array}{l}-0.4 I \\
+0.1 I \\
+0.18 \\
+0.31\end{array}$ \\
\hline $\begin{array}{c}\text { I4 } \\
\text { (days 33-39) }\end{array}$ & $\begin{array}{l}-\dagger \\
2 \cdot 1 \\
3 \cdot 0 \\
4 \cdot 0\end{array}$ & $\begin{array}{l}- \\
5.0 \\
5.0 \\
5.0\end{array}$ & $\begin{array}{l}- \\
\text { I71 } \\
168 \\
\text { I58 }\end{array}$ & $\begin{array}{l}15 \\
150 \\
212 \\
266\end{array}$ & $\begin{array}{l}- \\
49 \cdot 6 \\
50 \cdot 5 \\
54.9\end{array}$ & $\begin{array}{l}- \\
+0.18 \\
+0.15 \\
+0.21\end{array}$ \\
\hline $\begin{array}{c}14 \\
\text { (days } 40-46 \text { ) }\end{array}$ & $\begin{array}{l}2 \cdot 1 \\
2 \cdot 9 \\
4 \cdot 0\end{array}$ & $\begin{array}{l}4 \cdot 5 \\
4 \cdot 5 \\
4 \cdot 5\end{array}$ & $\begin{array}{l}151 \\
149 \\
142\end{array}$ & $\begin{array}{l}134 \\
200 \\
236\end{array}$ & $\begin{array}{l}50 \cdot 4 \\
5 I \cdot 6 \\
56 \cdot 0\end{array}$ & $\begin{array}{c}(-0.04) \\
-0.19 \\
-0.22\end{array}$ \\
\hline $\begin{array}{c}I 4 \\
\text { (days } 47-65)\end{array}$ & $\begin{array}{l}4 \cdot 1 \\
3 \cdot 2 \\
4 \cdot 2\end{array}$ & $\begin{array}{r}5 \cdot 1 \\
8 \cdot 7 \\
10 \cdot 3\end{array}$ & $\begin{array}{l}166 \\
250 \\
261\end{array}$ & $\begin{array}{l}147 \\
340 \\
460\end{array}$ & $\begin{array}{l}52 \cdot 8 \\
6 r \cdot 9 \\
74 \cdot 3\end{array}$ & $\begin{array}{l}+0.18 \\
+0.97 \\
+1.98\end{array}$ \\
\hline
\end{tabular}

* Slope of the weight gain against time curve for the period following the first 4 days (Expts 12 and r3) or for the entire period (Expt I4). The values in parentheses were not significantly different from zero. $\uparrow$ Discontinued.

Maintenance of body-weight under ad lib. feeding conditions

Judged by the criteria adopted (p. 444), the maintenance protein levels and the corresponding maintenance requirements of ideal protein estimated from the results obtained in Expts I-8 (Table 2; Fig. I) were about $\mathrm{I} \cdot 2 \%$ (120 $\mathrm{mg} \mathrm{N} / \mathrm{day}^{\mathrm{kg}}{ }^{\mathbf{7} 73}$ ) for egg albumin, about $2 \%$ (160 mg) for herring meal, about $2.7 \%$ (rgo mg) for casein, about $2.8 \%$ ( $185 \mathrm{mg}$ ) for linseed meal, about $3.5 \%$ (230 mg) for soya-bean meal, about $4 \%$ and about $3.5 \%$ (I50 and $130 \mathrm{mg}$ ) for wheat gluten, and about $4.5 \%$ (270 mg) for pea meal. Maintenance of body-weight was not attained on the diets containing zein fortified with lysine and tryptophan at protein levels below 10 $\%$. 

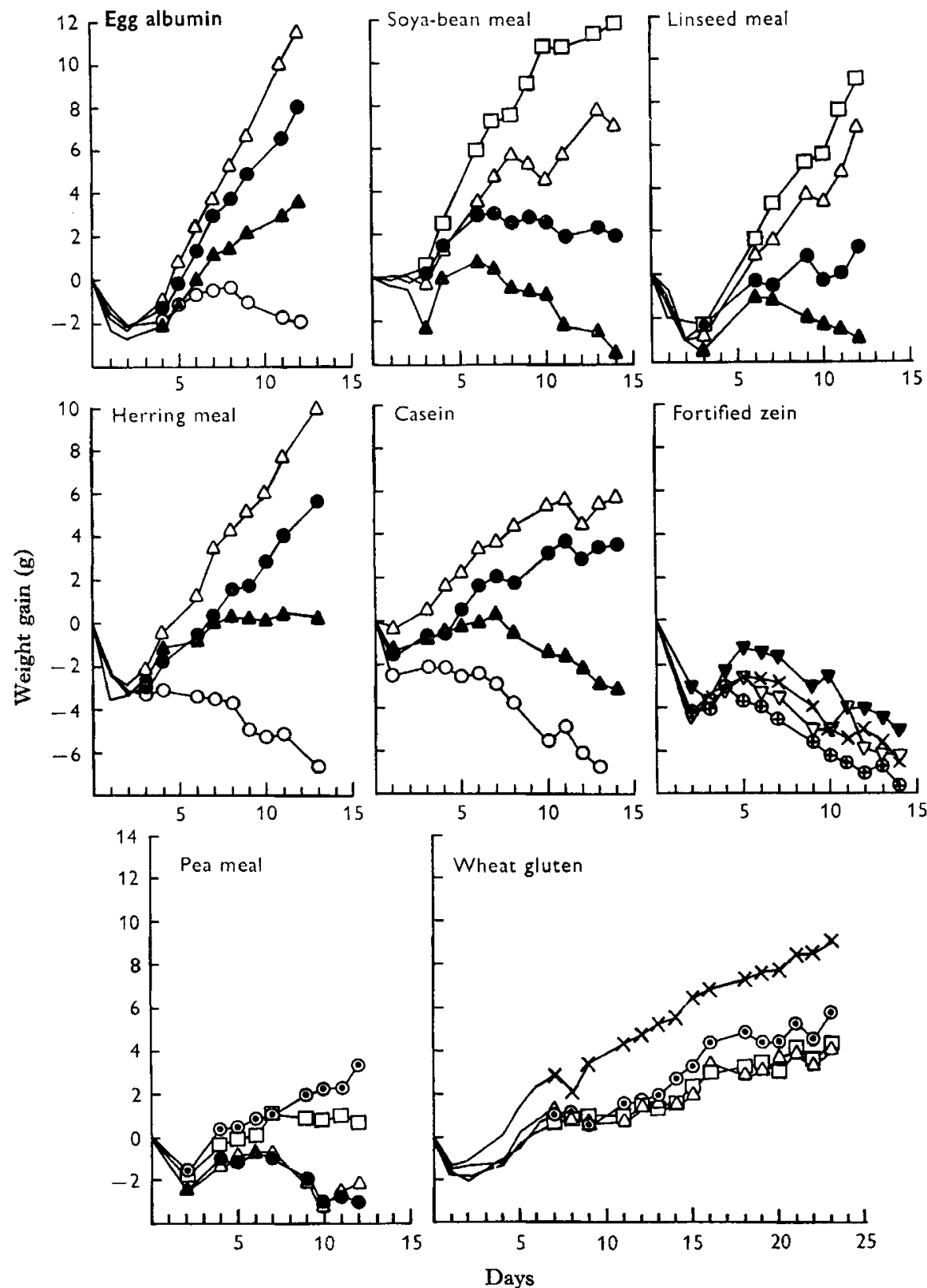

Fig. I. Expts 1-8. Mean cumulative weight-gain curves for groups of five or six rats given eight protein sources, each at four protein levels. $0-0,1 \cdot 0 \%$ egg albumin, $1 \cdot 1 \%$ herring meal, $1.0 \%$ casein; 4-4, $2.0 \%$ egg albumin, $2.1 \%$ soya-bean meal, $2.1 \%$ linseed meal, $\mathbf{2} .2 \%$ herring meal, $2.0 \%$ casein; $-\bullet, 2 \cdot 9 \%$ egg albumin, $3.2 \%$ soya-bean meal, $3.1 \%$ linseed meal, $2.9 \%$ herring meal, $3.1 \%$ casein, $2.9 \%$ pea meal; $\Delta-\Delta, 3.9 \%$ egg albumin, $4.5 \%$ soya-bean meal, $4.0 \%$ linseed meal, $4.3 \%$ herring meal, $4.2 \%$ casein, $4.0 \%$ pea meal, 4.4 and $4.0 \%$ wheat gluten; $\square-\square, 5.5 \%$ soya-bean meal, $5.1 \%$ linseed meal, $4.6 \%$ pea meal, 5.5 and $5.0 \%$ wheat gluten; $\odot-\odot, 5.6 \%$ pea meal, 6.5 and $5.9 \%$ wheat gluten; $x-x, 6.8 \%$ fortified zein, 7.8 and $7.0 \%$ wheat gluten; $\oplus-\oplus, 7.7 \%$ fortified zein; $\nabla-\nabla$, $8.9 \%$ fortified zein; $\boldsymbol{\nabla} \longrightarrow$, I0. I \% fortified zein. 
The results obtained in Expt 9 with herring meal, linseed meal, wheat gluten and pea meal agreed fairly well with these estimates (Table 3 ; Fig. 2), whereas the results with egg albumin indicated that the maintenance protein level was higher than $\mathrm{I} \cdot 6 \%$ and that the maintenance requirement of protein was higher than $130 \mathrm{mg} N$. The results obtained in Expts Io and I $\mathrm{I}$ indicated that the maintenance protein level was about $2 \%$ and the maintenance requirement about $190 \mathrm{mg} \mathrm{N}$. The maintenance protein level of about $2 \%$ for egg albumin was not significantly affected when the

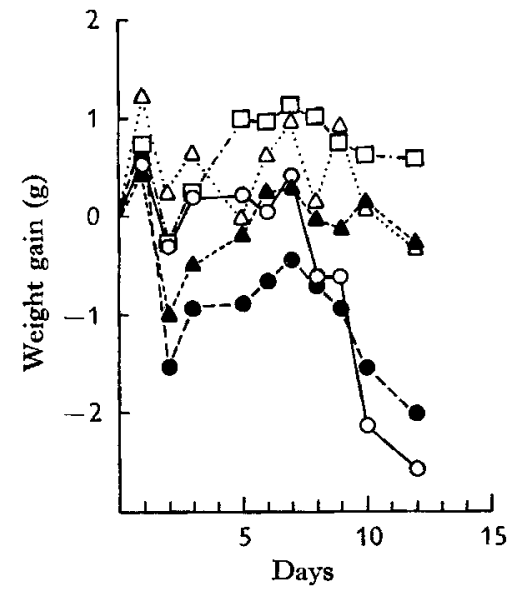

Fig. 2

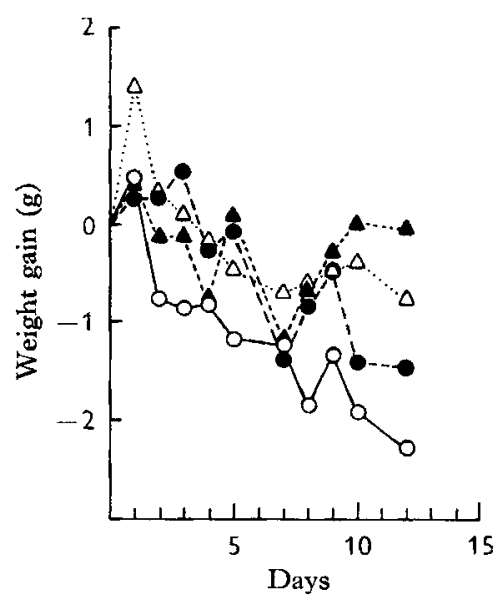

Fig. 3

Fig. 2. Expt 9. Mean cumulative weight-gain curves for groups of six rats given five protein sources at protein levels near to the maintenance levels. $0-0,1.6 \%$ egg albumin; $\bullet-. \bullet$, $\mathbf{2} .0 \%$ herring meal; $\triangle-.-\Delta, 2.9 \%$ linseed meal; $\square-.-\square, 3.4 \%$ wheat gluten; $\Delta . . . . . \Delta, 4.9 \%$ pea meal.

Fig. 3. Expt 10. Mean cumulative weight-gain curves for groups of six rats given egg albumin as protein source at the $2.3 \%$ protein level in diets containing two types of carbohydrate ingredient with $(+)$ and without $(-)$ added water. $\Delta \ldots . . \Delta$, partly dextrinized potato starch, sucrose $(-)$; $\bullet-.-\bullet$, partly dextrinized potato starch, sucrose $(+) ; 0-0$, raw potato starch, rice starch, sucrose $(-) ; \mathbf{A - - - \Lambda , ~ r a w ~ p o t a t o ~ s t a r c h , ~ r i c e ~ s t a r c h , ~ s u c r o s e ~}(+)$.

diet was given wet or dry (Expt I0; Fig. 3), by either type of carbohydrate ingredients in the diet (Expt Io; Fig. 3), or by a change of the temperature in the animal rooms from 22 to $28^{\circ}$ (Expt I r Fig. 4). The maintenance requirement was with egg-albumin protein lower at $28^{\circ}$ than at $22^{\circ}$, about 135 and $190 \mathrm{mg} \mathrm{N} /$ day $\mathrm{kg}^{0 \cdot 73}$, respectively (Expt I I, Table 4 ; Fig. 4).

In the groups approximately maintaining their mean body-weight at $22^{\circ}$ the mean daily food intake ranged from $5 \cdot 4$ to $7 \cdot 4 \mathrm{~g} /$ rat (Expts 2-4, 7-I I T Tables 2-4). The diet contained by calculation about $3.8 \mathrm{kcal} / \mathrm{g}$, thus the daily calorie intake ranged from I 80 to $245 \mathrm{kcal} / \mathrm{kg}^{0} \cdot 73$. The calorie intakes in growing groups were not greatly different from this (Expts I-5, 7-9, II; Tables 2-4). Gain in weight was observed in only one experiment on an intake of less than $200 \mathrm{kcal} / \mathrm{day}_{\mathrm{kg}}{ }^{0.73}$ (Expt 8, period 2; Table 2). The calorie intake on the egg-albumin diet at the $2.3 \%$ protein level was not influenced by the addition of water to the diet or by the change of carbohydrate ingredients in it (Expt Io; Table 3). At $28^{\circ}$ the daily calorie intakes at $2 \cdot 1$ and $4 \%$ 
protein levels were lower than those observed at $22^{\circ}$. The latter were within the range usually observed at this temperature (I $80-245 \mathrm{kcal} / \mathrm{kg}^{0.73}$ ). At $28^{\circ}$ the daily intake of the $2.1 \%$ diet was equivalent to about $I_{5} 0 \mathrm{kcal} / \mathrm{kg}^{0 \cdot 73}$ and that of the $4 \%$ diet to about $\mathrm{I} 60 \mathrm{kcal} / \mathrm{kg}^{0 \cdot 73}$ (Expt i I; Table 4 ).

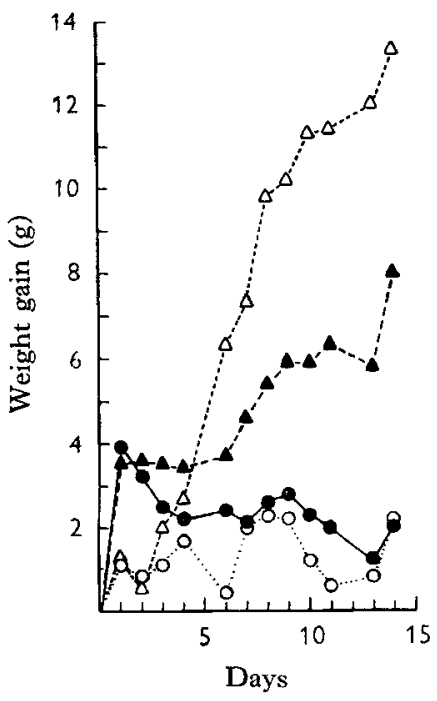

Fig. 4

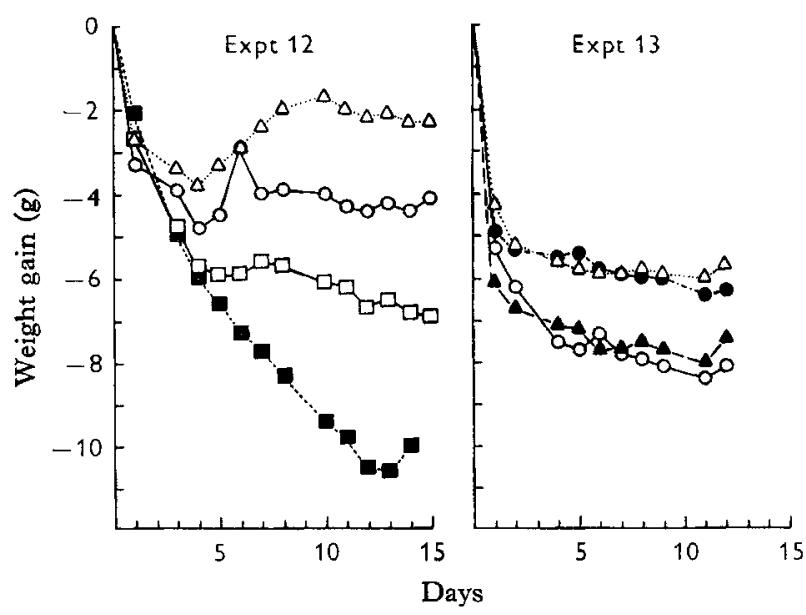

Fig. 5

Fig. 4. Expt I 1 . Mean cumulative weight-gain curves for groups of six rats given egg albumin as protein source at the $2 \cdot I$ and $4.0 \%$ protein levels at $22^{\circ}$ and $28^{\circ}$ room temperatures. $0 \cdots 0,2.1 \%, 22^{\circ} ; \bullet-\bullet, 2 \times 1 \%, 28^{\circ} ; \Delta \cdots-\Delta, 4.0 \%, 22^{\circ} ; 4--\Delta, 4.0 \%, 28^{\circ}$.

Fig. 5. Expts 12 and 13 . Mean cumulative weight-gain curves for groups of six rats given diets with egg albumin as protein source at a restricted daily amount of $4.5 \mathrm{~g} / \mathrm{rat}$ at different protein levels. --., ०\%; 口-- $2.0 \%, 0-0,40 \%$ (Expt 12), 4.2\% (Expt 13); $\Delta \ldots \Delta$, $6 \% ; \Delta--4,8 \cdot 2 \% ; \bullet . . \bullet, 10 \cdot 4 \%$.

\section{Maintenance of body-weight under conditions of restricted feeding}

When the egg-albumin diets were offered in restricted amounts the rats apparently maintained their body-weight at the I.O-I.I \% protein level (Expt I4, days 9-I4 and I 5-25, Table 5; Fig. 6). However, they refused some of the food offered, and after 32 days were so emaciated that the group had to be discarded. At the 2. I \% protein level the rats maintained their body-weight when the daily food intake was $5.5 \mathrm{~g}$ and $4.5 \mathrm{~g}$ (days 9-14, 26-32, and 40-46), and they grew at food intakes of $6.0 \mathrm{~g}$ and $5.0 \mathrm{~g}$ (days $1^{-25}$ and $33^{-39}$ ). They also grew at a slow rate when they were given free access to the food at a mean daily intake of $5^{\cdot} \mathrm{I} g$ (days $47^{-65}$ ). Thus, the maintenance protein level under conditions of restricted feeding is difficult to define but seems to be slightly less than 2.1\%. In Expts 12 and 13, but not in Expt 14 (Table 5 ; Figs. 5 and 6), the body-weight attained after the initial rapid loss during the first 4 days was approximately maintained at protein levels ranging from 2.0 to $10.4 \%$. The higher protein levels tended to give higher body-weights than lower levels.

The rats maintaining their body-weight, or growing slowly, at the $2 \cdot \mathrm{I} \%$ protein 
level seemed to require less calories and protein the longer the period of restriction (Expt 14, days 9-14, 26-32, 33-39 and 40-46, Table 5). When the rats were given free access to the food they grew slowly at about $170 \mathrm{kcal} / \mathrm{day}^{\mathrm{kg}} \mathrm{g}^{0.73}$ and about $15^{\circ} \mathrm{mg}$ $\mathrm{N} /$ day $\mathbf{~ k g}^{0.73}$ (days $47-65$ ). Under the latter condition there was also a clear tendency for the calorie intake to increase with increasing protein content of the diet, in contrast to the results obtained with unrestricted diets (Table 2).

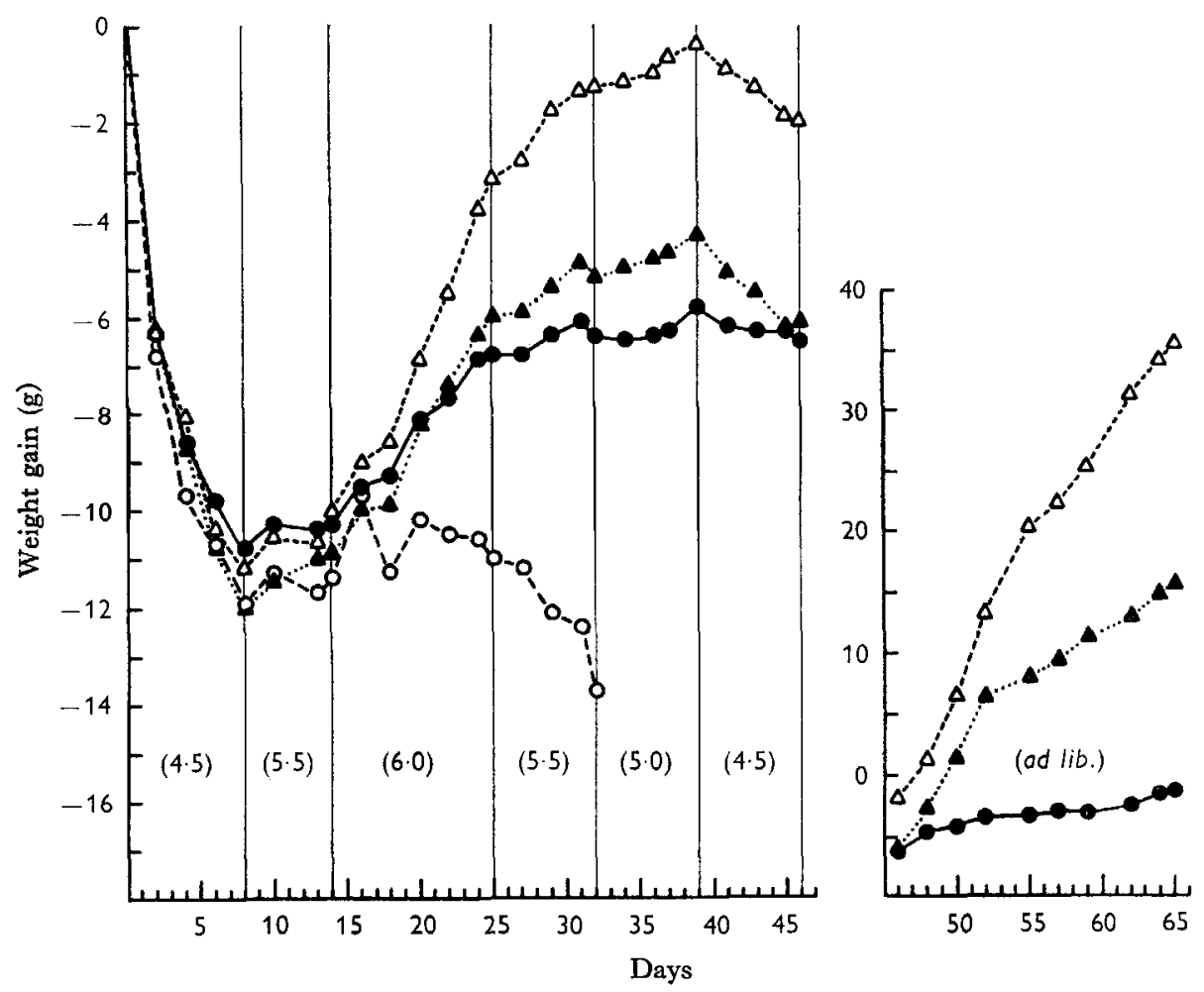

Fig. 6. Expt 14. Mean cumulative weight-gain curves for groups of six rats given diets with egg albumin as protein source at four protein levels and at various daily food intakes. $0---0$, I.0-1.1 \%; - $2.1 \% ; \Delta \ldots . . \Delta, 2.9-3.2 \% ; \Delta---\Delta, 3.9-4.2 \%$. The graphs were drawn on the basis of the weighings every 2 or 3 days. (The daily amounts (g) of food given are shown in parentheses.)

\section{DISCUSSION}

\section{Maintenance of body-weight under ad lib. feeding conditions}

The low levels of protein needed for maintenance found in these experiments confirm the suggestion made on theoretical grounds ( Njaa, I962) that maintenance levels predicted by the equation of Miller \& Payne (196I) are too high. The calorie intake of the rats maintaining their body-weight was about $200 \mathrm{kcal} /$ day $\mathrm{kg}^{0.73}$, and the mean calculated maintenance requirement for ideal protein was equivalent to about $19 \circ \mathrm{mg} \mathrm{N} /$ day $\mathrm{kg}^{0 \cdot 73}$. (The high value obtained with pea meal and the low value obtained with wheat gluten are commented upon below.) The corresponding quantities obtained by combining the equations given by Miller \& Payne (1961, 1962) 
were $156 \mathrm{kcal}$ and $250 \mathrm{mg} \mathrm{N}$. Thus, the higher food intakes in my experiments only partly explain the low maintenance protein levels observed. The different results could neither be explained by the practice of adding water to the diet ( $\mathrm{Njaa}, 1959)$, as might be suggested by the findings of Keane, Smutko, Krieger \& Denton (I962, I963), nor could they be due to improved protein utilization resulting from better utilization of the carbohydrate part of the diet (Heard, 1964; Expt 10). The higher food intake resulted from keeping the rats at $22^{\circ}$ as compared with $28^{\circ}$ used by Miller $\&$ Payne (Miller, 1963). However, the maintenance protein level seemed to be the same at both temperatures (Expt II) and the maintenance protein need consequently seemed to be higher at the lower temperature. The results obtained in Expt 9 with the egg-albumin diet indicate that the higher need was not merely due to the greater calorie intake at the lower temperature. The rats lost weight at a calorie intake equal to that observed for maintenance at $22^{\circ}$ and at a $\mathrm{N}$ intake equal to that observed for maintenance at $28^{\circ}$.

The calculated maintenance needs showed divergent results when the protein sources were wheat gluten and pea meal (Table 2). This may be explained for wheat gluten by assuming that the chemical score for maintenance is appreciably higher than for growth. It has been adequately demonstrated that the lysine requirement for maintenance is much lower than that for growth (Mitchell, 1947; Henry \& Kon, 1952) and the results of Barnes et al. (1946) indicate a nutritive value of wheat gluten for maintenance of 62 and for growth of 2I. The chemical score adopted for pea meal (FAO, 1957) is probably too high. Amino acid analyses by Block \& Mitchell (1946-7), Tsien \& Johnson (1959) and Schuphan \& Postel (1960) give chemical scores relative to the FAO (1957) amino acid pattern of 52, 45 and 33. Moreover, the chemical scores used by Carpenter (I95I) and cited by Munro (I964) indicate that the score for peas is about $35 \%$ relative to egg albumin. It is probable therefore that the chemical scores of wheat gluten and pea meal as given in Table $\mathrm{r}$ should be interchanged. This would be in agreement with the growth responses observed and it would bring the calculated maintenance protein needs into accord with those found with the other protein sources.

The estimate of $190 \mathrm{mg} \mathrm{N} / \mathrm{day}^{\mathrm{kg}} \mathrm{g}^{0.73}$ for the maintenance protein needs agrees well with that of Forbes et al. (1958) but it is higher than the estimate of Barnes et al. (1946). However, the results agree in indicating that the maintenance protein requirement is at most about $75 \%$ of the quantity suggested by Miller \& Payne (1962, 1964).

The finding, attributed to Goettsch (195I), that the maintenance protein requirement of rats equals $250 \mathrm{mg} \mathrm{N} /$ day $\mathrm{kg}^{0.73}$ (Miller \& Payne, 1964) warrants some comment. Her results recalculated to the basis of $\mathrm{kg}^{0 \cdot 73}$ gave $23^{\circ} \mathrm{mg} \mathrm{N} /$ day $\mathrm{kg}^{0.73}$ for rats weighing more than $\mathrm{I} 60 \mathrm{~g}$ and $\mathrm{I} 90 \mathrm{mg} \mathrm{N}$ for rats weighing less than this. However, it is doubtful whether it is permissible to base such estimates on experimentally determined NPU values, as was done by Goettsch (1951), because NPU already includes estimates of the two most important items of the maintenance requirement, namely metabolic faecal $\mathrm{N}$ and endogenous urinary $\mathrm{N}$.

The sum of these inevitable $\mathrm{N}$ losses is often used as an estimate of the maintenance 
requirement. It is of interest, therefore, to compare it with the estimates of the maintenance requirement obtained in the experiments now described and with those of Barnes et al. (1946) and Forbes et al. (1958). If the daily calorie intake at maintenance is $140 \mathrm{kcal} / \mathrm{kg}^{0.73}$ (Brody, I945) the corresponding food intake of a diet con-

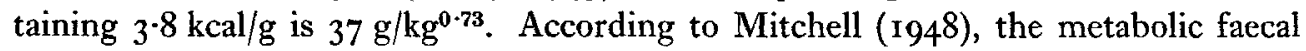
$\mathrm{N}$ excretion is $\mathrm{I}-2 \mathrm{mg} / \mathrm{g}$ food and the endogenous urinary excretion is $0.6 \mathrm{mg} / \mathrm{g}^{0.75}$. Corresponding values given by Metta (1960) are $2 \mathrm{mg} \mathrm{N} / \mathrm{g}$ food and $0.5 \mathrm{mg} \mathrm{N} / \mathrm{g}^{0.75}$. Thus the sum of these excretions would be about I40-175 $\mathrm{mg} \mathrm{N} / \mathrm{day}_{\mathrm{kg}}^{0.73}$. In the experiments presented now, performed at a lower room temperature, the calorie

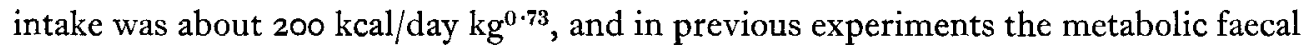
excretion was about $\mathrm{r} \cdot 9 \mathrm{mg} \mathrm{N} / \mathrm{g}$ food and the daily endogenous urinary excretion about $0.66 \mathrm{mg} \mathrm{N} / \mathrm{kg}^{0.75}$ (Njaa, ${ }^{1963}$ ). Thus, the sum of these excretions corresponds to about 2 I0 $\mathrm{mg} \mathrm{N} /$ day $\mathrm{kg}^{0 \cdot 73}$. The magnitudes of the metabolic and endogenous $\mathrm{N}$ losses are probably overestimated in the procedures used to determine them ( $\mathrm{Njaa}$, 1963) but, on the other hand, estimates of the maintenance protein requirement based on them do not take into account the $\mathrm{N}$ lost in hair. This loss is relatively small (Miller \& Payne, 1964) and may probably be more than compensated for by the overestimation of other $\mathrm{N}$ losses. In my experience an unusually great loss of hair was observed in one experiment with eighteen adult rats given low-protein diets. A I-day collection of hair from these rats weighed about $0.5 \mathrm{~g}$, which by calculation was found to be equivalent to a $\mathrm{N}$ loss of about $\mathrm{I} 2 \mathrm{mg} / \mathrm{day} \mathrm{kg}^{0 \cdot 73}$. This estimate of loss of $\mathrm{N}$ in hair should be regarded as an upper limit. Thus, the excretion data referred to give estimates of the maintenance protein requirement in good agreement with the estimates arrived at from the data of Barnes et al. (I946) and Forbes et al. (1958), and those obtained in the experiments now described.

\section{The effect of environmental temperature}

The temperature of the animal rooms in different laboratories varies between 20 and $30^{\circ}$, but it is often not stated. This was so with my own communications ( $\mathrm{Njaa}, 1959$, I961, 1962, 1963) and with those of Miller \& Bender (1955) and Miller \& Payne (I96I, I962). Recently Miller (1963) revealed that experiments were done at $28 \pm \mathrm{I}^{\circ}$ and argued that this temperature range is better suited for protein utilization studies than temperatures outside the range of thermal neutrality for the rat. However, Jacob \& Payne (1964) found that efficiencies of protein utilization were the same at ${ }_{5} 5$ and $25^{\circ}$ at low protein levels.

The results obtained in Expt I I indicated that the maintenance protein requirement was higher at $22^{\circ}$ than at $28^{\circ}$ although the maintenance protein levels were equal. The $4 \%$ group of rats grew at a slower rate at the higher temperature. A measure of the efficiency of protein utilization of the amount consumed above the maintenance needs is the quotient between the extra weight gain and the extra protein consumed, this quantity being $4^{\circ} \circ \mathrm{g} / \mathrm{g}$ protein for the $28^{\circ}$ group and $5^{\circ} \circ$ for the $22^{\circ}$ group. There seems therefore to be no advantage in measuring the protein utilization by criteria of weight-gain measurements within the range of thermal neutrality for the rat. Tem- 
peratures within this range are near to the point where temperature regulation breaks down (Swift \& Forbes, 1939; Herrington, 194I) and it may be questioned whether a temperature range found to be consistent with minimum metabolism under shortterm measurements on fasting rats is also the range for minimum metabolism of rats with free access to the food and kept for a longer period of time at the high temperature (Kleiber, 196r, p. 274).

For comparison of results on protein utilization between laboratories it seems to be important that the temperature of the animal rooms should be stated. Further, the effect of the temperature on growth, $\mathrm{N}$ balance and maintenance protein requirement should be given more attention in discussions of methods of protein evaluation.

\section{Maintenance of body-weight under conditions of restricted feeding}

The results obtained in Expt I4 showed that the rats on restricted diets were able to maintain their body-weight at lower intakes of calories than those required by rats fed $a d l i b$. This is in agreement with the results of Quimby (1948), Kaunitz, Slanetz, Johnson \& Guilmain (I956) and Lee \& Lucia (I96r) who showed that the calorie requirement of rats given sufficient food just acequate to maintain their body-weight tends to decline. This is probably a consequence of a reduced basal metabolism due to the conditions of restricted feeding. As the rats maintained their body-weight, or grew slowly, at the $2 . \mathrm{I} \%$ protein level, the maintenance protein requirement declined in parallel with the calorie requirement. Thus, under conditions of both ad lib. and restricted feeding the rats maintained their body-weight on slightly less than I $\mathrm{mg}$ $\mathrm{N} / \mathrm{kcal}$. When the rats were restricted from the beginning of the experiment to the calorie intake on which they eventually maintained their body-weight in Expt I4 there was a tendency for higher protein intakes to be required in order to maintain the body-weight attained after the first rapid weight loss (Expts 12 and I3).

\section{SUMMARY}

I. The protein levels required for the maintenance of body-weight at $22^{\circ}$ room temperature of young rats weighing $50-60 \mathrm{~g}$ were determined on groups of five or six rats with eight protein sources of widely differing chemical scores. Each protein source was given under ad lib. feeding conditions at four protein levels, of which at least the lowest was assumed to be below the maintenance level.

2. The maintenance protein level was about $2 \%$ for egg albumin and herring meal, between 2 and $3 \%$ for casein, about $3 \%$ for soya-bean meal and linseed meal, about $3.5 \%$ for wheat gluten and about $5 \%$ for pea meal. Zein fortified with lysine and tryptophan to give a chemical score of about 30 did not maintain body-weight when included at protein levels up to $10 \%$.

3. The daily intake of ideal protein (actual intake $\times$ chemical score) was reasonably constant at about $190 \mathrm{mg} \mathrm{N} / \mathrm{kg}^{0.73}$ when the rats maintained their body-weight on the seven protein sources. The corresponding calorie intake was about $200 \mathrm{kcal} / \mathrm{kg}^{\mathbf{0} \cdot 73}$; this quantity was not appreciably higher in growing rats. 
4. The type of carbohydrate in the diet and the practice of giving the diet wet or dry did not significantly influence the protein utilization of the egg albumin diet at the $2 \cdot 3 \%$ level.

5. When egg albumin protein was given at the $2 \cdot \mathrm{I}$ and $4 \%$ levels at 22 and $28^{\circ}$ room temperature, the body-weight was maintained at the $2.1 \%$ level at both temperatures. The food intake at both levels was lower at 28 than at $22^{\circ}$. Thus the maintenance protein requirement was lowest at the former temperature. The rats on the $4 \%$ protein diet grew faster at 22 than at $28^{\circ}$; the protein utilization measured as $g$ extra gain in weight per $g$ extra protein eaten above maintenance was slightly better at $22^{\circ}$. The importance of stating at which temperature protein utilization studies are performed is stressed.

6. Under conditions of restricted feeding with egg-albumin diets the $2 \cdot 1 \%$ protein level seemed to be near the maintenance level. The calorie intake and the amount of protein required for maintenance seemed to decline in parallel, so that the protein requirement was equal to about I $\mathrm{mg} \mathrm{N} / \mathrm{kcal}$ under conditions of both ad lib. and restricted feeding.

\section{REFERENCES}

Barnes, R. H., Bates, M. J. \& Maack, J. E. (I946). F. Nutr. 32, 535.

Bender, A. E. \& Doell, B. H. (1957). Br. F. Nutr. I1, 140.

Block, R. J. \& Mitchell, H. H. (1946-7). Nutr. Abstr. Rev. 16, 249.

Boge, G. (1960). F. Sci. Fd Agric. 11, 362.

Brody, S. (1945). Bioenergetics and Growth. New York: Reinhold Publishing Corp.

Cabak, V., Dickerson, J. W. T. \& Widdowson, E. M. (1963), Br. F. Nutr. 17, 601.

Carpenter, K. J. (I95 I). Br. F. Nutr. 5, 243.

FAO (1957). F.A.O. nutr. Stud. no. I6.

Forbes, R. M., Vaughan, L. \& Yohe, M. (1958). f. Nutr. 64, 291.

Goettsch, M. (195I). Y. Nutr. 45, 609.

Heard, C. R. C. (1964). Proc. Nutr. Soc. 23, r ro.

Henry, K. M. \& Kon, S. K. (1952). F. Dairy Res. r9, 216.

Henry, K. M. \& Toothill, J. (1962). Br. F. Nutr. 16, 125.

Herrington, L. P. (I94I). In Temperature, its Measurement and Control in Science and Industry, p. 446. [C. O. Fairchild, J. D. Hardy, R. B. Sosman and H. T. Wensel, editors.] New York: Reinhold Publishing Corp.

Jacob, M. \& Payne, P. R. (1964). Proc. Nutr. Soc. 23, v.

Kaunitz, H., Slanetz, C. A., Johnson, R. E. \& Guilmain, J. (1956). F. Nutr. 60, 22 I.

Keane, K. W., Smutko, C. J., Krieger, C. H. \& Denton, A. E. (1962). 7. Nutr. 77, 18.

Keane, K. W., Smutko, C. J., Krieger, C. H. \& Denton, A. E. (r963). F. Nutr. 8r, 87.

Kleiber, M. (1961). The Fire of Life. New York: Wiley.

Lee, M. \& Lucia, S. P. (196r). F. Nutr. 74, 243.

Metta, V. C. ( I 960). F. Am. diet. Ass. 37, 234.

Miller, D. S. (r963). Publs natn. Res. Coun., Wash., no. r roo, p. 34.

Miller, D. S. \& Bender, A. E. (1955). Br. F. Nutr. $9,382$.

Miller, D. S. \& Payne, P. R. (I961). Br. F. Nutr. I5, i I.

Miller, D. S. \& Payne, P. R. (1962). F. Nutr. 78, 255.

Miller, D. S. \& Payne, P. R. (1963). F. theor. Biol. 5, 398.

Miller, D. S. \& Payne, P. R. (1964). Proc. Nutr. Soc. 23, I I.

Mitchell, H. H. (1923-4). F. biol. Chem. 58, 873.

Mitchell, H. H. (1947). Archs Biochem. 12, 293.

Mitchell, H. H. (1948). In Proteins and Amino Acids in Nutrition. Ch. 2, p. 46. [M. Sahyun, editor.] New York: Reinhold Publishing Corp.

Munro, H. N. (1964). In Mammalian Protein Metabolism. Vol. 2, p. 3. [H. N. Munro and J. B. Allison, editors.] New York: Academic Press Inc.

National Research Council (1959). Publs natn. Res. Coun., Wash., no. 7 I I, p. 15.

Njaa, L. R. (1959). Br. F. Nutr. 13, 137. 
Njaa, L. R. (1961). F. Sci. Fd Agric. 12, 757.

Njaa, L. R. (1962). Br. F. Nutr. 16, 185.

Njaa, L. R. (1963). FiskDir. Skr. 4, no. 5 .

Quimby, F. H. (1948). F. Nutr. 36, r77.

Schuphan, W. \& Postel, W. (1960). Z. Lebensmittelunters. 113, 223.

Siemermann, B. (1959). Möglichkeiten zur Verbesserung der biologischen Eiweisswertigkeit durch Kombination verschiedener Eiweissfuttermittel. (Säulenchromatographische Aminosäurengehaltsbestimmungen in Soja-, Erdnuss-, Rops-, Kokos- und Palmkernschrot). Thesis, Bonn-

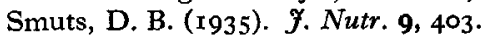

Swift, R. W. \& Forbes, R. M. (1939). F. Nutr. 18, 307.

Tsien, W. S. \& Johnson, B. C. (1959). F. Nutr. 68, 4 I9. 